\title{
Environmental Constitutionalism in the United States and Nigeria: Recognizing Environmental Rights
}

\author{
Theodore Okonkwo ${ }^{1}$ \\ ${ }^{1}$ Department of Public Law, Faculty of Law, University of Port-Harcourt, Port-Harcourt, Nigeria \\ Correspondence: Theodore Okonkwo, Department of Public Law, Faculty of Law, University of Port-Harcourt, \\ Port-Harcourt, Nigeria.
}

Received: May 18, 2017

Accepted: June 12,2017_Available online: June 19, 2017

doi:10.11114/ijsss.v5i7.2497

URL: https://doi.org/10.11114/ijsss.v5i7.2497

\begin{abstract}
Environmental constitutionalism is a scheme that protects the national and international environment by applying national and global constitutional law. By this, constitution-makers agree to include in their constitutions provisions aimed at environmental protection and sustainability, whereby procedural and substantive rights are written in the constitutions. The courts are in such jurisdictions called upon to enforce and protect such rights. This article addresses constitutionally embedded rights in the national constitutions of the United States of America and Nigeria. It analyzes constitutional environmental provisions in both how their judiciaries respond to such issues. This article looked at the problems associated with environmental constitutionalism in the United States and Nigeria and their connection with environmental rights. The aim is to take a holistic examination of the topic. The methodology adopted for the research is empirical. The primary and secondary sources of material selection were adopted through the use of the law libraries and the internet, books, journals and periodicals to gather information for this article. In conclusion, it was observed and recommended that no matter the similarities shared by the Untied States and Nigeria, the former has a more developed environmental jurisprudence on environmental protection by the courts. This is a truism, notwithstanding the fact that Nigeria's constitution contains "state environmental duties". The value of the research is that Nigeria should identify areas to be improved upon in its law and practice of environmental constitutionalism.
\end{abstract}

Keywords: constitution, constitutional law, environmental constitutionalism, environmental protection, environmental rights, procedural rights, substantive rights

\section{Introduction}

Boyd (2012) has argued that for "the past four decades, there has been a remarkable and ongoing shift toward constitutional recognition of the importance of protecting the environment." May and Daly (2014) wrote that "one must concede that the absence of constitutionalism does not mean the absence of environmental protection." This is so, because countries like the United States with a Constitution that is "pre-ecological,", which contains no "explicit or implicit' reference to environmental constitution or the United Kingdom which has no formal written constitution could not be said to be less concerned about environmental protection. May and Daly (2014) however, observed that "the absence of a constitution does, however, suggest a void, particularly as applied to environmental rights (May and Daly, 2014)." Constitutional commitment to environmental protection has helped advance the role of the courts to environmental protection. A ready case that comes to mind is Minors Oposa v. Secretary of the Department of Environment and Natural Resources, ${ }^{i i}$ where the Supreme Court of the Philippines relied on the Constitution of the Philippines 1987 to order the cancellation of the timber licenses at issue in that case. The point in this case of rele vance to this article was made by the Supreme Court on "the fact of constitutionalization" of environmental protection. The Supreme Court stated that Philippines Constitution 1987 imposes state environmental duties on the government "to protect and promote the health of the people and instill health consciousness among them."iii

Whether the rights recognized by means of environmental constitutionalism are positive rights, ${ }^{\text {iv }}$ or negative rights, procedural (May and Daly, 2014) or substantive rights, ${ }^{\mathrm{vi}}$ the important factor remains how functional and responsive such regime is. Constitutional environmental rights are useless if they are not "accompanied by an obligation upon the state to respect, protect, and, in some circumstances, take proactive steps to fulfill the right." This article argues that constitutional recognition of environmental rights without the governments establishing a strong institutional capacity 
and human resource to implement, monitor compliance and enforce environmental laws and regulations will only make 'the loftiest" environmental constitutional provisions mere empty platitudes.

The topic of this article is very important because Nigeria and the United States operate written federal constitutions, the former having borrowed it from the later. However, more importantly, is the fact that the United States is far more advanced in democracy and constitutionalism, thus, Nigeria has a lot to learn from them. Comparisons of the two countries will no doubt help Nigeria identify areas to be improved upon in its law and practice of environmental constitutionalism.

This article examines environmental constitutionalism in the United States in Part 2; Part 3 describes the environmental provisions as contained in the Constitution of the Federal Republic of Nigeria 1999 (as amended); Part 4 discusses how the courts respond to the environmental (provisions) rights in both the United States and Nigeria; Part 5 examines the issue of enforcement in both United States and Nigeria, Part 6 concludes the discussion.

\section{Environmental Constitutionalism in the United States}

In the United States, "constitutional recognition of the value of environmental protection" has failed to keep pace with global paradigm on environmental constitutionalism. The United States eighteenth century constitution does not explicitly or implicitly contain constitutional protection for the environment "including right to a healthy environment," although the United States courts has on several occasions allowed citizens and non-government groups to successfully maintain an action against the government and non-government actors for violations of federal environmental laws. ${ }^{\text {vii }}$

Jonathan Cannon acknowledges 'the constitutional setting" in the United States when he stated:

The US Constitution-the eighteenth century document establishing the nation's foundational arrangements - is pre-ecological. It makes no provision for environmental rights or authorities. It fairly bristles with elements of the dominant paradigm that sociologists cast as inimical to environmentalism: protection of private property rights, support for limited government, and freedom to pursue individual interests within a laissez-faire system. These are all backed by a thoroughgoing anthropocentrism. ${ }^{\text {viii }}$

Expressing concern that the United States constitution failed to recognize the value of environmental protection Jonathan Cannon continued:

The Constitution's failure to expressly address environmental concerns may be a function of its age, but it makes the United States an outlier internationally. Most of the world's constitutions (all of them younger) establish some form of a right to a healthy environment or government duty to protect it. There have been numerous suggestions for amending the U.S. Constitution along these lines, and a number of States in this country have adopted such amendments to their constitutions. But this avenue of change is difficult procedurally and of uncertain benefit. The experience of many of the states that have adopted these provisions is that the rights or obligations conferred are weakly enforced.

Although the Constitution lacks any provision specifically for the environment, several generic constitutional doctrines have figured importantly in the Court's environmental cases, mostly to the detriment of environmentalist claims. These include standing, federalism, and protection of private property against governmental takings. The court has used these doctrines to limit the scope of federal environmental protections and to condition access to the federal courts by citizens seeking to vindicate those protection.ix

Amending the constitution of the United States is not a tea party, "it is extremely difficult to amend the constitution (Boyd, 2012)." The fact that there is no express constitutional provisions for government to protect the environment in the United States does not mean that the government has shied away from its duty to protect the environment and individual right to live in a healthy environment. Cannon acknowledged the fact that several United States' states have amended their state constitutions to include environmental rights. This raises the issue of "sub-national deployment of environmental rights in the United States (May and Daly, 2001).” According to (May and Daly, 2014) citing Brooks, "sub-national deployment of environmental rights in the United States is instructive because it underscores both the potential and limitations of environmental constitutionalism." Craig (2004) while pointing out that "all efforts to amend the US Constitution to recognize environmental rights have failed," wrote that states in the United States have for long constitutionalized environmental protection. As far back as 1842 Rhode Island constitution provided, "all the rights of fishery, and the privileges of the shore" shall be protected. The section titled "Fishery rights-shore privileges preservation of natural resources" states: ${ }^{\mathrm{x}}$

Section 17 Fishery rights - Shore privileges - Preservation of natural resources.

The people shall continue to enjoy and freely exercise all the rights of fishery, and the privileges of the 
shore, to which they have been heretofore entitled under the charter and usages of this state, including but not limited to fishing from the shore, the gathering of seaweed, leaving the shore to swim in the sea and passage along the shore; and they shall be secure in their rights to the use and enjoyment of the natural resources of the state with due regard for the preservation of their values; and it shall be the duty of the general assembly to provide for the conservation of the air, land, water, plant, animal, mineral and other natural resources of the state, and to adopt all means necessary and proper by law to protect the natural environment of the people of state by providing adequate resource planning for the control and regulation of the use of the natural resources of the state and for the preservation, regeneration and restoration of the natural environment of the state.

The New York State Constitution" ${ }^{\mathrm{xi}}$ provides for sustainable economic development and maintenance of "Forever-Wild Forest" in the Adirondacks. Section 1 provides:

The lands of the state, now owned or hereafter acquired, constituting the forest preserve as now fixed by law, shall be forever kept as wild forest land. They shall not be leased, sold or exchanged or be taken by any corporation, public or private, nor shall the timber thereon be sold, removed or destroyed... ${ }^{\text {xi }}$

To protect the environment, the New York State Constitution emphasize the need of "harmony between people and nature in protected areas (Sun, 2010)." May and Daly (2014) have outlined the United States' states that presently recognize environmental protection to include: Louisiana, ${ }^{x i i}$ Michigan, $^{x i v}$ Ohio, ${ }^{x v}$ South Carolina ${ }^{x v i}$ and Virginia, ${ }^{x v i i}$ among several others. ${ }^{\text {viii }}$ It is therefore, evident that though the United States constitution "contains no reference, either explicit or implicit" to environmental provisions, the States have as far back as 1842 taken up the challenge and filled gap created by the federal constitution. In so doing, the states have addressed environmental protection concerns and incorporated various environmental provisions to include "different categories of natural resource", which encompass, water, timber, minerals, public trust, substantive rights, right to the environment (usually qualified with words like "clean" or "healthful" or "quality"), right to clean air and water, "freedom from excessive and unnecessary noise" and the natural, scenic, historic, and esthetic qualities of the environment (May and Daly, 2014).

Apart from the states in the United States filling the gap of environmental constitutionalism, federal environmental statutes and regulations have also responded to this challenge by "entirely" transforming "the landscape for environmental law (Lazarus, 2001)." According to Cannon, xix "these statutes constituted a (Hudson, 2015)" "quasi-constitutional reordering",xx "of federal law." The leading United States Federal environmental statutes which majorly has "filled" the constitutional gap are: the National Environmental Policy Act ("NEPA"); ${ }^{\text {xxi }}$ the Endangered Species Act ("ESA"); ${ }^{\text {xxii }}$ the Clean Water Act ("CWA") ${ }^{\text {xxiii }}$ and the Clean Air Act ("CAA"). ${ }^{\text {xxiv }}$

NEPA was enacted to protect ${ }^{\mathrm{xxv}}$ the United States environment, and is often referred to as "the Magna Carta of environmental protection". The Endangered Species Act (ESA), ${ }^{\mathrm{xxvi}}$ has been described by Cannon as "a rudimentary bill of rights for biodiversity.",xxii Lazarus (2001) captured it as having "unsettled existing standards of conduct" creating an absolute mandate that federal agencies not jeopardize the continued existence of endangered or threatened species or adversely modify their habitat. Ruhl (2009) writes that the main aim of the Act is to "provide a means whereby the ecosystems upon which endangered species and threatened species depend may be conserved." For Cannon, the ESA "remains a strong toll for species preservation, and it has earned its ecocentric stripes."xxviii

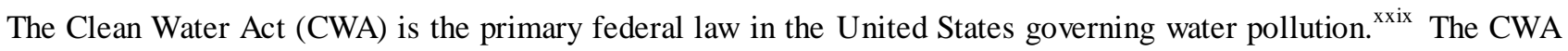
establishes the basic structure for regulating discharges of pollutants into the waters of the United States and regulating quality standards for surface waters. The Clean Air Act (CAA) is the comprehensive federal law that regulates air emissions from stationary and mobile sources. Among other provisions, CAA mandates EPA to establish National Ambient Air Quality Standards (NAAQS) to protect public health and public welfare and to regulate emissions of hazardous air pollutants. Cannon has argued that the CAA "differs slightly from the other statutes" because it focused majorly on human health. ${ }^{\mathrm{xx}}$ According to him, it meant 'to protect the nation's air quality so as to promote the public health and welfare and the productive capacity of its population."xxi The CAA was amended in 1977 and 1990 primarily to set new goals (dates) for achieving attainment of NAAQS.

\section{Environmental Constitutionalism in Nigeria}

Unlike the United States, the Constitution of the Federal Republic of Nigeria contains an explicit environmental provision "in the section that lays out policy directives, rather than fundamental rights (or otherwise justiciable rights)."xxxii It provides for state environmental duties in section 20 as follows: ${ }^{\text {xxiii }}$

The State shall protect and improve the environment and safeguard the water, air and land, forest and wild life of Nigeria.

This provision is contained in the chapter titled: "Fundamental Objectives and Directive Principles of State Policy,"xxxiv 
which is generally non-justiciable and unenforceable, but at best could only amount to a policy directive "rather than a guarantee of environmental protection." "xxx According to (Orji, 2013), there is however an implied reading and application of this provision that "the State recognizes the intimate linkages between the environment and human rights and that the failure of the State to protect the environment may interfere with individual human rights." Whatever the good intentions of the drafters of the 1999 Constitution may be has been whittled down by the "retrogressive non-justiciability (Duru, 2012)" contained in section 6(6) (c) of the Constitution which provides that the Judicial Powers $^{\text {xxxvi }}$ vested in the Courts mentioned in the Constitution:

Shall not, except as otherwise provided by this constitution, extend to any issue or question as to whether any act or omission by any authority or person or as to whether any law or any judicial decision is in conformity with the Fundamental Objectives and Directive Principles of the State Policy set out in Chapter II of this Constitution.

The Supreme Court of Nigeria has interpreted the "constitutional policy directives" to mean that the three organs of government, that is, the legislative, executive and judiciary are to observe, conform and apply the Fundamental Objectives and Directive Principles of State Policy. ${ }^{\text {xxxvii }}$

This article argues that while Chapter II on Fundamental Objectives and Directive Principles of State Policy is not justiciable, the content of section 20 of the 1999 Constitution of the Federal Republic of Nigeria presupposes environmental right. An environmental right has been defined as "the right of individuals and peoples to an ecologically sound environment and sustainable management of natural resources conducive to sustainable development." Being part of State policy, section 20 is not justiciable (Okonkwo, 2015). Section 33(1) of the Constitution of the Federal Republic of Nigeria 1999 provides that 'every person has a right to life and no one shall be deprived intentionally of his life.' This right seems to protect the right of citizens against environmental degradation. Many argue that this right to life along with section 20 confirm a right to a healthy environment.

There has been attempts to enforce section 20 through the constitutional right to life and dignity and through regional treaties and Charters like the African Charter on Human and Peoples' Rights. ${ }^{\text {xxxviii }}$ The earlier attempt was made in the case of Gani Fawehinmi v. Abacha, ${ }^{x x i x}$ where the Nigerian Court of Appeal held that the human rights in the African Charter on Human and Peoples' Rights having been enacted into Nigerian national law, was superior to a Decree. The African Charter 1981, Article 24 provides that the right to a satisfactory environment for development is a human right.

This article argues that a citizen can therefore rely on Article 24 of the Charter to enforce his environmental right instead of relying on section 20 of the 1999 Constitution which is not justiciable (Atsegbua, 2001). The Court has also recognized that environmental degradation can give rise to a violation of human rights. ${ }^{\mathrm{x}}$ In the case of Okpala v. Shell Petroleum Development Company (SPDC), ${ }^{x l i}$ the Federal High Court declined to recognize such a right. The court did not decide on the issue of whether there is a right to a clean and healthy environment, the constitutional right to life and dignity. Here, the court "refused to find an enforceable right to a clean and healthy environment through the African Charter," stating the rights guaranteed under the African Charter does not come within the provision of section 46(1) of the Constitution of the Federal Republic of Nigeria, which provides for the citizens the right to sue to enforce a violation of fundamental rights (Orji, 2013). Burns (2001), has depicted the Nigerian situation in the following terms:

Nigeria is a case study in unrealized potential. Its Supreme Court has the opportunity to find an enforceable right to the environment for its people, either through its own constitution or through the African Charter. But, the Court has refused. Between an unwilling judiciary and a corrupt government that has paid little attention to the environmental catastrophes in the Niger Delta, the Nigerian Constitution's promise of environmental protection will go unfulfilled (Burns, 2001).

It is therefore clear that by including section 20 under Chapter II of the Constitution, described as "Fundamental Objectives and Directive Principles of State Policy," the quality of the environmental objectives contained in section 20 is destroyed, and the content of the environmental objectives are reduced to worthless platitudes, by section 13 of the 1999 Constitution because it is non-justiciable and cannot ordinarily be enforced by the courts.

This article argues that the environmental objectives contained in section 20 of the Constitution carries with it the correlative duty to refrain from impairing the environment. It implies the right among other things, the judicious management and conservation of the country's forests. Without such forests and the constitutional right to water, the ecological or environmental balance would be irreversibly disrupted (Okonkwo, 2015).

\section{How the Courts Respond to the Environmental Provisions (Rights) both in the United States and Nigeria Constitutions}

While a constitutionally incorporated right to a quality environment at the national level is critically recommended, it is only useful and effective 'when it is recognized and enforced judicially (Jucker, 2006).' The situation in United States 
and Nigeria shows that it is not enough to have provisions in the statute books or the constitution concerning environmental protection or environmental rights, without translating these rights into reality. Despite "the varied manifestations of constitutionally embedded environmental provisions" at the national level, "the dispositive factor" is very much lacking as these provisions are "seldom subject to substantive interpretation," thus they remain "dormant" and await "clarity through" the judiciary. ${ }^{\text {xlii }}$ This problem of enforcement is likely due to fears on the part of the judiciary about "recognizing and enforcing emerging constitutional features (McLaren, 1990)." There is the palpable fear of "restraining economic development and property rights' which the judiciary fear may cause political thickets" and lead to criticisms of usurping legislative functions (May, 2004). This fear is sometimes well-founded as the courts' hands are tied due to the fact that some of these constitutional provisions on environmental rights are not "self-executing." A constitutional provision is self-executing when it can be given effect without the aid of legislation, and there is nothing to indicate that legislation is intended to make it operative. For example, section 20 in Chapter II of Nigeria's 1999 Constitution on environmental objectives is not self-executing. It requires further legislative action to make it enforceable or justiciable. ${ }^{\text {xliii }}$ What section 20 of Nigeria's 1999 Constitution did is to merely set forth a line of environmental policy or principles without supplying the means by which they are to be effectuated. ${ }^{\text {liv }}$

\subsection{United States}

The United States constitution as seen earlier contains no implicit or explicit environmental protection provisions, except in the case of some states. ${ }^{x l v}$ In the United States where environmental constitutionalism is not explicitly nor implicitly embodied in the constitution, the judiciary, at both the state and national levels, plays a key role in interpreting both textual environmental constitutional provisions and explicitly, non-constitutional environmental provisions (Hudson, 2015). While environmental protection in the United States is not enshrined in the constitution, the Federal statutes appear to have filled the gap. The language of most statutory environmental protection provisions are "powerful, broad and sweeping" and "reads like a constitutional promise of environmental rights." A case in point is the NEPA which has been notably referred to as the "Magna Carta of environmental protection" in the United States. This Act $^{\text {xlvi }}$ in its first section ${ }^{\text {xlvii }}$ provides that:

The Congress recognizes the profound impact of man's activity on the inter-relations of all components of the natural environment, particularly the profound influences of population growth, high density urbanization, industrial expansion, resource exploitation, and new and expanding technologically advances and recognizes further the critical importance of restoring and maintaining environmental quality to the overall welfare and de velopment of man, declares that it is the continuing policy of the Federal Government, in cooperation with State and local governments, and other concerned public and private organizations, to use all practicable means and measures, including financial and technical assistance, in a manner calculated to foster and promote the general welfare, to create and maintain conditions under which man and nature can exist in productive harmony, and fulfill the social economic, and other requirements of present and future generations of Americans. ${ }^{\text {xlviii }}$

NEPA furthered its environmental protection mandate by making it 'the continuing responsibility of the Federal Government to use all practicable means, consistent with other essential considerations of national policy, to improve and coordinate Federal plans, functions, programs, and resources to the end that the Nation may - fulfill the responsibilities of each generation as trustee of the environment for succeeding generations." "xlix The Act also provided that such "continuing responsibility" must be carried out in a way and manner to "assure for all Americans safe, healthful, productive and esthetically and culturally pleasing surroundings,", "attain the widest range of beneficially uses of the environment without degradation, risk to health of safety or other undesirable and unintended consequences,", and "enhance the quality of renewable resources and approach the maximum attainable recycling of depletable resources., "lii

Despite its laudable "magna carta" provisions, NEPA has been described as "a history of defeat (Green, 2015)" in the United States Supreme Court. ${ }^{\text {liii }}$ Green argues that since NEPA's enactment in 1970, it has been the focus of seventeen Supreme Court cases. ${ }^{\text {liv }}$ According to Green, government and industry have defeated environmental organizations in each of the seventeen cases and this scenario is very worrisome as it has whittled down the intendment of the Act. The U.S. Supreme Court has characterized NEPA as "essentially procedural" in all these cases, thus diminishing "the substantive mandate" of the Act. The Supreme Court has maintained that the Act "did not allow courts to substitute their judgment for an agency's or to elevate environmental factors over any other appropriate facts," notwithstanding "the strong and unambiguous language" contained in section 1 of the Act. ${ }^{\text {lv }}$ In the case of Strycker's Bay Neighbourhood Council v. Karlen, ${ }^{l v i}$ the Supreme Court struck down the Second Circuit's use of NEPA for "the substantive standards necessary to review the merits of agency's decisions".

According to Cannon, ${ }^{\text {lvii }}$ as of 2015, in the seventeen cases ${ }^{\text {lviii }}$ that the Supreme Court has decided on the merits 
regarding NEPA, those bringing actions on behalf of environmental interests have never succeeded. The Supreme Court has failed to interpret NEPA "to guarantee positive rights," even a "proto-constitutional" "right to environmental protection." "lix The Supreme Court has refused to read into the provisions of NEPA which is a statute with strong broad language the explicit mandate "to control the needless degradation of the natural environment." It is not however, all bashings for the Supreme Court of the United States as Lazarus (2012) explains that the United States Supreme Court has decided seventeen cases arising under the National Environmental Policy Act (NEPA) and the government has not only won every case, but won almost all of them unanimously.

The United States courts also respond to environmental rights protection enforcement by deciding cases brought before them under the mantra of citizen suits. Citizen suits are particularly common in the field of environmental law. For example, a citizen can sue a corporation under the Clean Water Act (CWA) for legally polluting a waterway. ${ }^{1 \mathrm{x}}$ Environmental laws that allow citizen suits include: Clean Water Act; ${ }^{1 \mathrm{xi}}$ Safe Drinking Water Act; ${ }^{\mathrm{lxii}}$ Clean Air Act; ${ }^{\mathrm{liii}}$ Resource Conservation and Recovery Act; ${ }^{\text {lxiv }}$ Comprehensive Environmental Response, Compensation, and Liability Act; ${ }^{1 \times v}$ Surface Mining Control and Reclamation Act; ${ }^{1 x v i}$ Endangered Species Act; ${ }^{1 x v i i}$ Emergency Planning and Community Right to Know Act. ${ }^{\text {lxvii }}$

The U.S. courts could grant plaintiffs in citizen suits injunctive and civil remedies restraining violators of environmental laws, though under strict requirement that the plaintiff must have standing to sue. Alder has written that until the Supreme Court case of Friends of the Earth, Inc. v. Laidlaw Environmental Service, Inc., ${ }^{\text {lxix }}$ it appeared that a majority of the Supreme Court would keep many environmental citizen-suit plaintiffs out of court (Adler, 2001)." In Lujan v. Defenders of Wildlife $e^{l x x}$ and other cases ${ }^{\mathrm{lxxi}}$ the Supreme Court's majority "placed constitutional and prudential limits on standing for environmental citizen suits." This "trend" has been so much criticized as the "most profound setbacks for the environmental movement in decades (Glaberson, 1999)." The dissenting Blackmun, J., berated the majority in Lujan case of "taking" a "slash and burn expedition through the law of environmental standing." Ixxii the losing counsel accused the Supreme Court of driving environmental attorneys "out of business (Coyle and Lavelle, 1992)."

In the case of Laidlaw, ${ }^{\text {lxxiii }}$ the Supreme Court "reversed course," and lowered the standing requirement. ${ }^{\text {lxxiv }}$ Notwithstanding the decision in Laidlaw case this article argues that "whether a liberalized standing regime enhances or undermines environmental protection" is a question for further research.

\subsection{Nigeria}

In Nigeria, the courts have enforced the right to a healthy environment as part of the constitutional right to life. ${ }^{\text {lxxv }}$ They do this following the provisions contained in the African Charter, ${ }^{1 \mathrm{xxvi}}$ this is so, even as this is not expressly provided for in the 1999 Constitution of the Federal Republic of Nigeria (Bruch, Coker, \& VanAvsdale, 2007). In the case of Jonah Gbemre (for himself and representing Iwhrekan Community in Delta State, Nigeria) v. Shell Petroleum Development Company Nigeria Ltd., Nigerian National Petroleum Corporation and Attorney-General of the Federation, ${ }^{l x x v i i}$ the applicant, Jonah Gbemre, on behalf of the Iwhrekan community, claimed inter alia as follows: A declaration that the actions of the 1st and 2nd Respondents (i.e. SPDC and Nigerian National Petroleum Corporation (NNPC) respectively) in continuing to flare gas in the course of their oil exploration and production activities in the Applicant's community is a violation of their fundamental rights (including healthy environment) and dignity of hum an person guaranteed by sections 33(1) and 4(1) of the Constitution of the Federal Republic of Nigeria, 1999 and reinforced by Articles 4, 16 and 24 of the African Charter on Human and Peoples Rights (ACHPR) (Ratification and Enforcement)Act Cap A9 Vol. 1 Laws of the Federation of Nigeria 2004. The Applicant also sought a declaration that the provisions of section 3(2)(a),(b) of the ACHPR and section 1 of the ACHPR Regulations under which the continued flaring of gas in Nigeria may be allowed are inconsistent with the Applicant's right to life and/or dignity of human person enshrined in section 33(1) and 34(1) of the Constitution, 1999 and Articles 4, 16 and 24 of the African Charter on Human and Peoples Right (Ratification and Enforcement) Act and are therefore unconstitutional, null and void by virtue of section 1(3) of the same Constitution. The Federal High Court sitting in Benin city granted all the reliefs as prayed and ordered the Attorney-General of the Federal Republic of Nigeria to immediately set into motion, after due consultation with the Federal Executive Council, necessary processes for the enactment of a Bill for an Act of the National Assembly for the speedy amendment of the relevant sections of the ACHPR and the ACHPR Regulations made there-under to quickly bring them in line with the provisions of chapter 4 of the Constitution. Thus, the Nigerian Federal High Court affirmed the fact that Shell's act of gas flaring in Nigeria's Niger Delta is "a gross violation of the fundamental right to life (including healthy environment) and dignity of human person as enshrined in the Constitution." "lxxviii

In Oronto Douglas v. Shell Petroleum Development Co. Ltd \& Others, ${ }^{l x i x}$ the Nigerian Court of Appeal set aside the decision of the learned trial Judge Belgore, C.J. on the 17th day of February, 1997, that refused to grant standing to the Applicant who argued that the construction of a hazardous liquefied natural gas plant without a proper environmental 
impact assessment has not been conducted strictly in accordance with the terms of the Environmental Impact Assessment Act 1992. The Applicant alleged that this violated his right to a healthy environment under the Article 24 of the African Charter (Ladan, 2009).

The plaintiff now appellant was an activist in the protection of the environment. He was actively involved in the protection of the environmental rights, promotion of waste management and generally safe and sustainable environment. He claimed to be a native of the Niger Delta where there are large deposits of oil and gas. The respondents were jointly engaged in a project for the production of liquefied natural gas. For the project to take off the respondents were required to do preliminary studies on the impact of the project on the environment. They were required to comply with the provisions of Environmental Impact Assessment Decree No. 86 of 1992. The appellant was not satisfied that the respondents had satisfactorily adhered to the provisions of the Decree hence he took an action, he discontinued the claim against the agency.

The appellant simultaneously filed the writ of summons with an originating summons. The claim in the writ of summons were for declaration and injunction restraining the respondents from continuing on and/or carrying on with the Liquefied Natural Gas project until a proper environmental impact assessment has been conducted strictly in accordance with the terms of the Decree aforesaid. In the originating summons the appellant submitted three questions for determination.

The appellant attached to the originating summons statement of facts and an affidavit verifying the statement. The 1st, 2nd, 3rd and 4th respondents filed notices of preliminary objection contending in the main appellant's actions were incompetent in that the appellant lacked the requisite locus standi and that the mode of the commencement of the appellant's actions is procedurally defective.

Arguments were heard by the trial Judge on the preliminary objection and in his ruling delivered on the 17th day of February, 1997, the trial judge Belgore, CJ. struck out the appellant's claim on the ground that the procedure adopted was "confused" and also on the ground that the appellant had no legal standing to prosecute the action. It was against this decision that the appellant had filed this appeal. This court held that since res in the matter had not been validly determined it will be imprudent for it to discuss the issues raised in the appeal. So it set aside the decision of the learne d trial Judge Belgore, C.J., on the 17th day of February, 1997.

Ladan (2009) has argued that the "prospects for asserting constitutional environmental rights in Nigeria are limited because courts are subject to political interference and adhere to strict rules on standing procedure and costs." The environmental protection regime in Nigeria is a total failure as the state's environmental duties at the local and national levels are wantonly ignored by state actors and non-state actors, thus, leaving the citizens with no other option than to approach "the court for appropriate judicial remedy (Amechi, 2009)" in cases where their constitutional right to a healthy environment "have been affected." Chapter IV of the 1999 Constitution of the Federal Republic of Nigeria does not make express provision of right of citizens to environment "among its fundamental right," but provides "for substantive rights like the rights to life, dignity of human person, private and family life, equality, and property that can be expansively interpreted to include the right to a healthy environment. "1xxx Howe ver, the 1999 Constitution of Nigeria contains "procedural rights than can be mobilized for environmental protection." "Ixxi There still remains the difficulty of using the courts to enforce environmental protection coupled with "weak state" environmental duties and lack of political will to enforce compliance. This difficulty manifested in the cases of Jonah Gbemre v. Shell P.D.C; ${ }^{\text {lxxii }}$ Ekeremor Zion v, Shell P.D.C. (see Human Rights Watch, 1999), and the Four Fishermen v. Shell P.D.C. lxxiii $^{2}$ These cases presented perfect opportunities for the courts in Nigeria to acquit itself of environmental judicial indolence, but this was not to be so. Shell aided by Nigeria's government officials always used "legal stalling in order to evade justice."

As discussed earlier, the 1999 Constitution of the Federal Republic of Nigeria makes no provision on the citizen's right to a healthy environment, except the skirting provision contained in section 20 titled "environmental objectives" made non-justiciable by its inclusion in Chapter II of the Constitution. However, this article argues as it has done earlier, that the inclusion of the section 20 in Chapter II of the Constitution titled "Fundamental Objectives and Directive Principles of State Policy" does not detract from the fact that citizens of Nigeria can still exercise and enforce their right to a healthy environment outside that provision. On this, Article 24 of the African Charter on Human and Peoples' Rights (2004) resonates. Nigeria has domesticated this Charter as part of her national law. The Act's long title and the content of the first section are very clear on the domestication of the Act. The long title states:

[A]n Act to enable effect to be given in the Federal Republic of Nigeria to the African Charter on Human and Peoples' Rights made in Banjul on the 19th day of January, 1981 and for purposes connected therewith. ${ }^{\text {lxxiv }}$

Section 1 is in the following terms: 
As from the commencement of this Act, the provisions of the African Charter on Human and Peoples' Rights which are set out in the Schedule to this Act shall, subject as there-under provided, have force of law in Nigeria and shall be given full recognition and effect and be applied by all authorities and persons exercising legislative, executive or judicial powers in Nigeria. ${ }^{1 \times x \times v}$

This provision was tested in the case of Abacha v. Fawehinmi, ${ }^{\text {lxxvi }}$ where the Supreme Court held that the African Charter is part of the Laws of the Federal Republic of Nigeria and the courts must uphold it like all other laws. The courts are bound to enforce the rights and obligations contained in it. Thus, (Rhuks, 2010) has argued that "if the substantive right to a healthy environment is to have any meaning, it must be judicially enforceable." ${ }^{\prime x x x v i i}$

Rhuks has further rightly stated that "despite regional progress in the recognition of Nigeria's right to enjoy a healthy environment, it appears that the country's judiciary is still circumspect with regard to interpreting extant legal provisions." "lxxxviii However, there are few cases where the Nigerian courts appear to have expressed support albeit, not expressly on the constitutional right to a healthy environment. ${ }^{\text {.xxxix }}$

\section{Issue of Enforcement in Both United States and Nigeria}

The issue of enforcement in both the United States and Nigeria depends on "whether a right should be recognized under the constitutional framework, the country has established". In the United States, environmental constitutional rights are more receptive and responsive to enforcement than Nigeria where they are stunted by the government's insincerity, hypocrisy and corruption. In the United States enforcement is strong and vigorous, unlike Nigeria where it is very weak and decrepit. In both United States and Nigeria enforcement depends on whether the rights are substantive or procedural. Though America's constitution contains no substantive environmental rights provisions, in practice citizens and institutions resort to the Fifth Amendment (Amendment V) to the Untied States Constitution which is part of the Bill of Rights and the United States national Environmental Policy Act (NEPA).

In Nigeria, "state environmental duties" is found in section 20 of the Constitution of the Federal Republic of Nigeria 1999 (As Amended) in Chapter II which is not ordinarily enforceable by the courts. However, Nigeria courts have ruled that the right to a healthy environment includes the right to life, "even where no explicit constitutional provisions exist". In the United States, the United States Environmental Protection Agency (U.S.E.P.A.) is charged with the responsibility of enforcing environmental laws in order to protect human health and the environment. U.S.E.P.A works to ensure compliance with environmental requirements and when necessary takes civil or criminal enforcement action against defaulters of environmental laws. One of U.S.E.P.A.'s cardinal mandate is to protect communities that are adversely affected by pollution through environmental justice (EJ). They identify cases to be pursued and ensure compliance and enforcement. Enforcement actions in the United States may take any or both of the following forms: civil administrative actions; civil judicial actions or criminal actions. In cases of civil enforcement actions, settlements are generally agreed-upon, which might be settlements in administrative actions by way of consent agreements, final orders or administrative orders on consent. There are also settlements in judicial actions whereby consent judgments are executed by all the litigating parties and filed in the appropriate court. Civil enforcement results also include civil penalties, injunctive relief and supplemental environmental projects and mitigation. Criminal enforcement by federal, state or local authorities result mostly in fines imposed by the courts when sentencing the offenders. At times, restitution may also be ordered. The courts also in appropriate cases may sentence an offender to prison. The unique approach adopted in the United States, which Nigeria lacks is the publishing of Annual Enforcement Results showing the results of U.S.E.P.A.'s enforcement activities for the previous fiscal year. There is also the Enforcement and Compliance Data which U.S.E.P.A. uses to manage and identify performance of its enforcement and compliance assurance program.

In Nigeria, though the federal and state laws provide for civil and criminal enforcements for violation of environmental laws, these laws are rarely applied and enforced, violators are mostly let off the hook by government enforcing officials "on settlement", meaning bribery. The system is too enmeshed in corruption that when an environmental matter eventually gets to the courts, the court officials and the judges collect bribes from the defendants and ask them to go home free individuals. Fines and or compensation are not even awarded. This deliberate non-commitment and corruption by the government and institutions entrusted with enforcing environmental laws has stunted the growth of environmental constitutionalism in the country. Akin to the above is the fact that Nigeria's civil and government workers are owed salaries for years and this in itself entrenches corruption in the system. A worker who is being owed over 24 months salary in order to survive and take care of his family brazenly resorts to gratification and bribery from offenders in return for setting them free. In most cases, paltry payment to a court official will guarantee that the case does not come up for trial or at times that the case records mysteriously gets "missing". It all depends on how large a sum of money the offender is willing to pay. The judge, the government lawyer prosecutor and the court administrative staff are all together in this corruption industry. In the end, the importance and essence of environmental protection is lost to the society at large. The government then takes the blame, rightly, it is submitted as it fails to provide the courts 
with the wherewithal to effectively enforce constitutional environmental rights of citizens. Based on the foregoing, the environmental constitutional provisions becomes mere empty platitudes because both the state and its officials have to together neglected their constitutional duty "to protect and improve the environment and safeguard the water, air and land, forest and wildlife of Nigeria".

\section{Conclusion}

This article has examined environmental constitutionalism in the United States and Nigeria and their respective approaches in recognizing environmental rights. Two issues certainly bestride both countries environmental law regimes: the challenges of enforcement and the court's responses to the environmental provisions (rights) in their constitutions and statute books. The United States is a well developed country and Nigeria is still an emerging economy with a fragile and often flouted constitutional framework and inchoate environmental protection regime. It is true that the United States Constitution, does not contain environmental rights protection provisions, but there are four crucial federal environmental statutes ${ }^{\mathrm{xc}}$ and a host of others ${ }^{\mathrm{xci}}$ that are comparable or even stronger than environmental constitutional provisions which provide "broad, sweeping guarantees, establishing the new environmental policy of the nation and securing environmental quality for its people." "xii But unfortunately, the courts have reduced those statutes to mere rhetorical by insisting on the principle of standing which is premised on the U.S. Constitution. Under Article III of the U.S. Constitution, judicial power extends over "cases" and "controversies," and this has been interpreted to mean that only lawsuits claiming an injury to the plaintiff can be heard by the federal courts (Martin, 2008). The plaintiff must show an "injury-in-fact" that is "concrete and particularized" and "actual or imminent," the plaintiff must demonstrate a "causal connection between the injury and the conduct complained of" and the plaintiff's injury must be one that is likely to be redressed by a favourable decision in the case. ${ }^{\text {xciii }}$

In Nigeria, the courts are not generally informed on environmental constitutionalism and are mostly confused, as Belgore C.J. confirmed in the case of Oronto Douglas, ${ }^{x c i v}$ that the "papers" filed were "confusing" and so refused to grant "standing" to the applicant, though the Court of Appeal overturned the lower court's decision. The courts in Nigeria "shy away from asserting" that citizens have the right to enjoy a healthy environment." In the United States, unlike in Nigeria, citizen suits and public interest litigation in environmental matters are recognized by the courts. This article argues that in both United States and Nigeria, lack of "clarity regarding the rules and procedures with respects to locus standi hinders access to justice... (Ako, 2010)". Nonetheless, though it seems that environmental rights receive better attention and protection when expressly contained in the country's constitution, the United States and Nigeria experiences shows that this is not usually the position. Either can fail or succeed, that is the "constitutional and statutory rights can succeed and both can fail." " ${ }^{\mathrm{cv}}$ The determinant factor here remains the courts, in most cases the country's apex courts. It lies with them to "determine" whether those constitutional and statutory environmental provisions are recognized environmental rights capable of enforcement by the courts. In most cases, plaintiffs leave the courtrooms with broken hopes and dreams.

This article concludes by arguing that no matter the similarities shared by the United States and Nigeria, the former has a more developed environmental jurisprudence on environmental protection by the courts. This is a truism, notwithstanding the fact that Nigeria's constitution contains "state environmental duties." "xcvi The value of this research therefore rests on the pillar of Nigeria borrowing those aspects of United States environmental constitutionalism that can effectively be incorporated into their national law and constitution in order to further and advance the law on environmental protection. Limitations and gaps howe ver remain in both countries environmental constitionalism which this article hopes will be addressed by future research on the topic.

\section{References}

Adler, J. H. (2001, Fall). Stand or deliver: Citizen suits, standing, and environmental protection. Duke Environmental Law and Policy Forum, 12, 39.

African Charter on Human and Peoples' Rights (Ratification and Enforcement) Act A9 . (2004). Laws of the Federation of Nigeria.

Ako, R. T. (2010). The judicial recognition and enforcement of the right to environment: Differing perspectives from Nigeria and India. NUJS Law Review, 423, 433, 434.

Amechi, E. P. (2009). Poverty, Socio-Political Factors and Degradation of the Environment in Sub-Saharan Africa: The Need for a Holistic Approach to the Protection of the Environment and Realization of the Right to Environment Law, Environment and Development Journal, 5/2(107), 110.

American Psychological Association. (1972). Ethical standards of psychologists. Washington, DC: American Psychological Association.

Atsegbua, L. (2001). Environmental rights, pipeline vandalisation and conflict resolution in Nigeria IELTR, 89-92. 
Boyd, D. R. (2012). The Environmental Rights Revolution: A Global Study of Constitutions, Human Rights, and the Environment. The University of British Columbia Press, 47.

Bruch, C., Coker, W., \& VanAvsdale, C. (2007). Constitutional Environmental Law: Giving Force to Fundamental Principles in Africa (2nd ed). Environmental Law Institute. Washington, DC.

Burns, K. (2001). Despoliation and destitution: Whither environment and human rights in Nigeria's Niger Delta?' ILSA J. Int'l \& Corp. L., 8,1 .

Coyle, M., \& Lavelle, M. (1992, June). Quoting Brian O’Neil. Eco-groups standing curtailed. NAT'L L.J., 3.

Craig, R. K. (2004). Should there be a constitutional right to a clean/healthy environment? Environmental Law Report, 34(12), 1103.

Duru, O. (2012). The Justiciability of Fundamental Objectives and Directive Principles of State Policy Under Nigerian Law. Retrieved from www.http://ssrn.com/abstract=2140361 (accessed on March 12, 2017).

Glaberson, W. (1999). Novel Anti-pollution Tool Is Being Upset by Courts, New York Times, June 5, p. A1.

Green, Z. C. (2015). NEPA in the Supreme Court: A History of Defeat. Master of Environmental Assessment Thesis, Raleigh, North Carolina.

Hudson, B. (2015). Structural environmental constitutionalism Journal Articles. Paper 170, p. 210. Retrieved from www.http://digitalcommons.law.lsu.edu/faculty-scholarships/170 (accessed March 13, 2017).

Hudson, B. (2015). Structural environmental constitutionalism’ Journal of Articles Paper 70, Louisiana State Uni versity Law Centre.

Human Rights Watch. (1999). The Price of Oil Corporate Responsibility and Human Rights Violations in Nigeria's Oil Producing Communities, London.

Ladan, M. (2009). Nigeria. In Kotze, L. J. \& Paterson, A. R. (Eds.). The Role of the Judiciary in Environmental Governance Comparative Perspectives. The Hague: Kluwer Law International.

Lazarus, R. (2012). The national environmental policy act in the U.S. Supreme Court: Areappraisal and a peek behind the curtains. The Georgetown Law Journal, 100, 1507.

Lazarus, R. J. (2001). The greening of America and the graying of United States environmental law: reflections on environmental law's first three decades in the United States Va. Envtl. L.J. 20, 75, 76-77.

Martin, M. A. (2008). Standing: Who can sue to protect the environment? Social Education, 72(3), 113-117.

May, J. R. (2004). The Availability of State Environmental Citizens Suits. Natural Resources and Environment, $18,53$.

May, J. R., \& Daly, E. (1992). Citing Brooks, R.O. Aconstitutional right to a healthful environment Vermont Law Review, $16,1063,1103-5,109$.

May, J. R., \& Daly, E. (2014). Global Environmental Constitutionalism. Cambridge University Press, 36. https://doi.org/10.1017/cbo9781139135559

May, J. R., \& Daly, E. (2001). (in Eurick, J. P.). The constitutional right to a healthy environment: enforcing environmental protection through state and federal constitutions International Legal Perspectives, 11, 185.

McLaren, R. A. (1990). Environmental Protection Based on State Constitutional Law: A Call for Reinterpretation. University of Hawaii Law Review, 12, 149.

Okonkwo, T. (2015). Environmental constitutionalism in Nigeria: Are we there yet? Nig. J.R., 13, $175,178$.

Orji, U. J. (2013). Right to a clean environment: some reflections, Envtl. Pol'y \& L., 42, 285, 286.

Rhuks, T. (2010). The Judicial Recognition and Enforcement of the Right to Environment: Differing Perspectives from Nigeria and India, NUJS Law Review, 423, 433, 434.

Rhul, J. B. (2009). Keeping the endangered species act relevant. Duke Envtl. L. and Pol'y F., 19, $275,280$.

Sun, C. Y. (2010). Interpreting Article XIV of the New York Constitution: The Legal Measures that Mandate Sustainable Economic Development and Maintenance of Forever-Wild Forest in the Adirondacks Pace Law School Student Publications Paper 4. Retrieved from www.http://digitalcommons.pace.edu/lawstudents/4

Tucker, J. C. (2006). Constitutional codification of an environmental ethic Florida Law Review, 52, 299. 


\section{Endnotes}

i Burns, K. (2016). Constitutions and the Environment: Comparative Approaches to Environmental Protection and the Struggle to Translate Rights into Enforcement. Environmental Law Review Syndicate 1 citing JZ Cannon, Environment in the Balance: The Green Movement and the Supreme Court (Harvard University Press 2015) 29, where Jonathan Cannon interprets a wide range of U.S. Supreme Court decisions over four decades to gauge the practical and cultural impact of environmentalism and its future prospects.

ii 33 ILM 173 (1994).

iii See, Section 15, Article II, Philippines Constitution, 1987.

iv Duties placed on the government to protect the environment.

$\checkmark$ Preventing discharges of pollution into air and water.

vi ibid 64-83, 249-251.

vii Glisson v. City of Marion, 720 N.E. 2d 1034, 1042 (111. 1999).

viii Cannon, J. Z., ibid 29.

ix ibid 29.

x Article 1, section 17, Constitution of the State of Rhode Island and Providence Plantations 1842.

xi Article XIV section 1 .

xii Constitution of the State of New York, as adopted in 1938, with amendments, Mc-Kinney's Consolidated Laws of the State of New York. Article IX, section 1, Louisiana State Constitution. Article IV, section 51, Michigan State Constitution.

xv Article VIII, section 2, Ohio State Constitution.

xvi Article XII, section 1, South Carolina State Constitution.

xvii Article XI, section 1, State of Virginia Constitution.

xviii Presently, 46 State constitutions contain environmental protection related provisions.

xix Cannon, J.Z., ibid 33.

xx Cannon, J. Z., ibid.

xxi 1969, 42 U.S.C. Sections 4321-70m (2012).

xxii 1973, 16 U.S.C. sections 1531-1544 (2012).

xxiii As amended in 1972, 33 U.S.C. sections 1251-1387 (2012).

xxiv 1963 (with amendments in 1970, 1977 and 1990), 42 U.S.C. sections 7401-7671q 92012).

xxv See, JC Sweeney, 'Protection of the Environment in the United States'(1989) 1 Fordham Envtl. L. Rep. 1, 15.

xxvi The Endangered Species Act of 1973 (ESA) was signed on December 28, 1973.

xxvii Cannon, J. Z., ibid 35.

xxviii Cannon, J. Z., ibid 35.

xxix The first FWPCA was enacted in 1948, but took on its modern form when completely rewritten in 1972 in an Act entitled the Federal Water Pollution Control Act of 1972.

xxx Cannon, J. Z. ibid 36.

xxxi ibid.

xxxii Burns, K. ibid (note 1 above).

xxxiii Chapter II, section 20, 1999 Constitution of the Federal Republic of Nigeria.

xxxiv ibid.

xxxv ibid.

xxxvi See section 318, Constitution of the Federal Republic Nigeria 1999 for the definition of "powers".

xxxvii See, section 13 of the Constitution of the Federal Republic of Nigeria which appears to be in conflict with section 6(6) (c) of same Constitution. See also the case of Arch-Bishop Olubunmi Okogie v. The Attorney-General, xxxviii 1981.

xxxix (1996) 9 NWLR, Part 475 at 710.

x1 Kokoro-Owo v. Lagos State Government (1995) 6 NWLR 760 at 765.

xli Suit No. FHC/PHC/C5/518/2006 of 29 September, 2006. 
xlii In Sierra Club v. Department of Transportation 167 P. 3d 292, 313 cited by JR May and E Daly ibid at note 50 page 221, the Supreme Court of Hawaii, 2007, explained that "[a] lthough this court has cited this amendment as support for our approach to standing in environmental cases... we have not directly interpreted the text of the amendment". See, Arch-Bishop Olubunmi Okogie v. The Attorney-General of Lagos State (1981) 2 NCLR 337. See, section 13, 1999 Constitution, Federal Republic of Nigeria.

xliv See, Attorney-General of Ondo State v. Attorney-General of the Federation (2002) 9 NWLR (Part 772) 222 and Olafisoye v. Federal Republic of Nigeria (2004) 4 NWLR (Part 864) 580.

xlv Alabama (Article 11, section 219. 07(1)); California Article 10, section 2); Colorado (Article 18, section 6); Florida (Article 2, section 7); Hawaii (Article 11, section 9); Idaho (Article 15, section 1); Illinois (Article 11, section 2); Louisiana (Article 9, section 1); Massachusetts (Article 97); Michigan (Article 13, section 52); Minnesota (Article 13, section 12); Missouri (Article 3, section 37); Montana (Article 2, section 3); New Mexico (Article 20, section 21); New York (Article 14, section 1); North Carolina (Article 14, section 5); Ohio (Article 8, section 2); Oregon (Article 11, section 2); Pennsylvania (Article 2, section 27); Puerto Rico (Article 6, section 19); Rhode Island (Article 1, section 17); Utah (Article 18, section 1) and Virgina (Article 11, section 2).

xlvi National Environmental Policy Act (as amended) 42 U.S.C. sections 4321 et seq.

xlvii Title 1 - Policies and Goals: Congressional Declaration of National Environmental Policy, 42 U.S.C. 4331.

xlviii 42 U.S.C. 4331 section 101(a), (2012).

xlix 42 U.S.C. 4331 section 101(b)(1), (2012)

$1 \quad 42$ U.S.C. 4331 section 101(b)(2), (2012)

li ibid at section 4331(b) (3), (2012).

lii ibid at section 4331(b) (6), (2012).

liii ibid.

liv See, U.S. v. SCRAP (1973; Averdeen \& Rockfish RR v. SCRAP (1975); Flint Ridge Development Co. v. Scenic Rivers Association of OK (1976); Kleppe v. Sierra Club (1976); Vermont Lankee Nuclear Power Corp. v. Natural Resources Defence Council (1978); Andrus v. Sierra Club (1979); Strycker's Bay Neighbourhood Council, Inc. v. Karlen (1980); Weinberger v. Catholic Action of Hawaii (1981); Metropolitan Edison v. People Against Nuclear Energy (1983); Baltimore Gas \& Electric Co. v. Natural Resources Defense Council (1982); Robertson v. Methow Valley Citizens Council (1989); Marsh v. Oregon Natural Resources Council (1989); Robertson v. Seattle Audubon Society (1992); Department of Transportation v. Public Citizen (2004); Norton v. Southern Utah Wilderness Alliance (2004); Winter v. Natural Resources Defense Council (2008); Monsanto Co. v. Geertson Seed Farms (2010).

Iv Vermont Yankee Nuclear Power Corp. v. NRDC, 435 U.S. 519, 558 (1978); Kleppe v. Sierra Club, 427 U.S. 390, 410

lvi 444 U.S. 223 (1980).

lvii Cannon, J. Z. ibid (note 1 above) at 34.

lviii See note 84 above.

lix ibid.

Ix Citizen suit - Wikipedia available at www.http://en.m.wikipedia.org (accessed on March 13, 2017). See also, 42 U.S. Code sections 7604 - Citizens suits.

1xi 33 U.S.C. sections 1251 et seq. (1972).

lxii 42 U.S.C. sections 300 fet seq. (1974).

lxiii 42 U.S.C. sections 7401 et seq. (1970).

lxiv 42 U.S.C. sections 6901 et seq. (1976).

lxv 42 U.S.C. sections 9601 et seq. (1980).

lxvi 33 U.S.C. sections 1201-1328; 91 Stat. 445 (1977).

lxvii 16 U.S.C. sections 1531 et seq. (1973).

Ixviii 42 U.S.C. sections 11001 et seq. (1986).

lxix 528 U.S. 167 (2000).

1xx 504 U.S. 555 (1992).

1xxi See, Steel Co. v. Citizens for a Better Env't 523 U.S. 83 (1998), Lujan v. National Wildlife Fed'n 497 (1990). 
1xxii ibid at 605 .

lxxiii ibid (note 100 above).

lxxiv Friends of the Earth, Inc. et al v. Laidlaw Environmental Services, Inc. 528 U.S. 167 (2000), was a United States Supreme Court Case that addressed the law regarding standing to sue and mootness.

${ }^{1 \times x v}$ Jonah Gbemre v. Shell Petroleum Development Company Nigeria Ltd and Others, Federal High Court of Nigeria, Benin Division, Judgment of 14 November 2005, Suit No. FHC/B/CS/53/05; Oronto Douglas v. Shell Petroleum Development Company Ltd. (1999) 2 N.W.L.R. (Part 591); Gani Fawehinmi v. Abacha (1996) 9 N.W.L.R. (Part 475) 710.

lxxvi African Charter on Human and Peoples'Rights 1981, Article 24.

lxxvii ibid, also see (2005) AHRLR 151 (NSHC 2005).

lxxviii ibid, this decision is under appeal meanwhile oil and gas pollution persists in the Niger Delta posing "severe environmental and health problems in the region."

Ixxix (1998) LPELR - CA/L/143/97.

lxxx ibid at 324 .

lxxxi See, sections 36, 39 and 40, 1999 Constitution, Federal Republic of Nigeria. See, generally the following cases:

Okogie v. Lagos State (1981) 2 NCLR 337; Adewole v. Jakande (1981) 1 N.C.L.R. 152; A.-G. Ondo State v. AG

Federation (2002) 9 Sup. Ct. Monthly 1 (Nig. Supreme Ct.); A-G, Abia State v. A-G., Federation (2003) 4 NWLR (Part 809) 124 at 175D-H; Abacha v. Fawehinmi (2000) FWLR 585G-P; 586 A-C; AND 623 G. lxxxii ibid.

lxxxii $\quad$ See, Court of the Hague in the matter with case number/docket number C/09/337/HAZA09 - 1580 of Friday Alfred Akpan \& The Association with Corporate Personality Verveniging Millieudefensie v. The Legal Entity Organized under Foreign Law Royal Dutch Shell Plc. and the Legal Entity Organized Under Foreign Law Shell Petroleum Development Company Ltd.

Ixxiv Long title to the Act, ibid.

lxxxv ibid, section 1 .

lxxxvi ibid.

lxxxvii Social and Economic Rights Action Centre and the Centre for Economic and Social Rights (SERAP) v. Nigeria. Communication No. 155/96; (2001) AHRLR 60.

lxxxviii ibid, at 435. See, Allan Irou v. Shell BP Suit No. W/89/91, Warri HC/26/11/73 (Unreported).

Ixxix S.P.D.C Ltd. v. Farah (1995) 3 NWLR (Part 382) 148, Edise v. William International Ltd. (1986) 11 CA 187 and S.P.D.C. Ltd.v. Tiebo (1996) 4 NWLR (Part 445, 657).

xc National Environmental Policy Act of 1969 (NEPA); Clean Air Act of 1963; Clean Water Act of 1972 and Endangered Species Act of 1973.

xci CERCLA (Superfund) of 1980, Coastal Management Act of 1966; Federal Land Policy and Management Act of 1976; Federal Insecticide, Fungicide, and Rodenticide Act of 1910; Federal Power Act of 1920; Fisheries Conservation and Management Act (Magnuson-Stevens) of 1976; Migratory Bird Treaty Act of 1916, and several others

xcii Burns, K. ibid.

xciii Lujan v. Defenders of Wildlife, 504 U.S. 555 (1992), where the three-part requirement for standing was outlined. See also Massachusetts v. EPA 549 U.S. 497 (2007); The majority cited Georgia v. Tennessee Copper Co., 206 U.S. 230, 237 (1907).

xciv ibid.

xcv Burns, K. ibid.

${ }^{x c v i}$ Section 20, 1999 Constitution of the Federal Republic of Nigeria.

\section{Copyrights}

Copyright for this article is retained by the author(s), with first publication rights granted to the journal.

This is an open-access article distributed under the terms and conditions of the Creative Commons Attribution license which permits unrestricted use, distribution, and reproduction in any medium, provided the original work is properly cited. 